This item was submitted to Loughborough's Research Repository by the author.

Items in Figshare are protected by copyright, with all rights reserved, unless otherwise indicated.

\title{
Ambalavaner Sivanandan and black politics in Britain
}

PLEASE CITE THE PUBLISHED VERSION

https://doi.org/10.1177/0263276418799874

PUBLISHER

SAGE Publications ()$^{-T h e}$ Author

VERSION

AM (Accepted Manuscript)

PUBLISHER STATEMENT

This work is made available according to the conditions of the Creative Commons Attribution-NonCommercialNoDerivatives 4.0 International (CC BY-NC-ND 4.0) licence. Full details of this licence are available at: https://creativecommons.org/licenses/by-nc-nd/4.0/

\section{LICENCE}

CC BY-NC-ND 4.0

\section{REPOSITORY RECORD}

Dasgupta, Rohit. 2019. "Ambalavaner Sivanandan and Black Politics in Britain”. figshare. https://hdl.handle.net/2134/28339. 


\section{$\underline{\text { Ambalavaner Sivanandan and Black Politics in Britain }}$}

Rohit K Dasgupta, Loughborough University

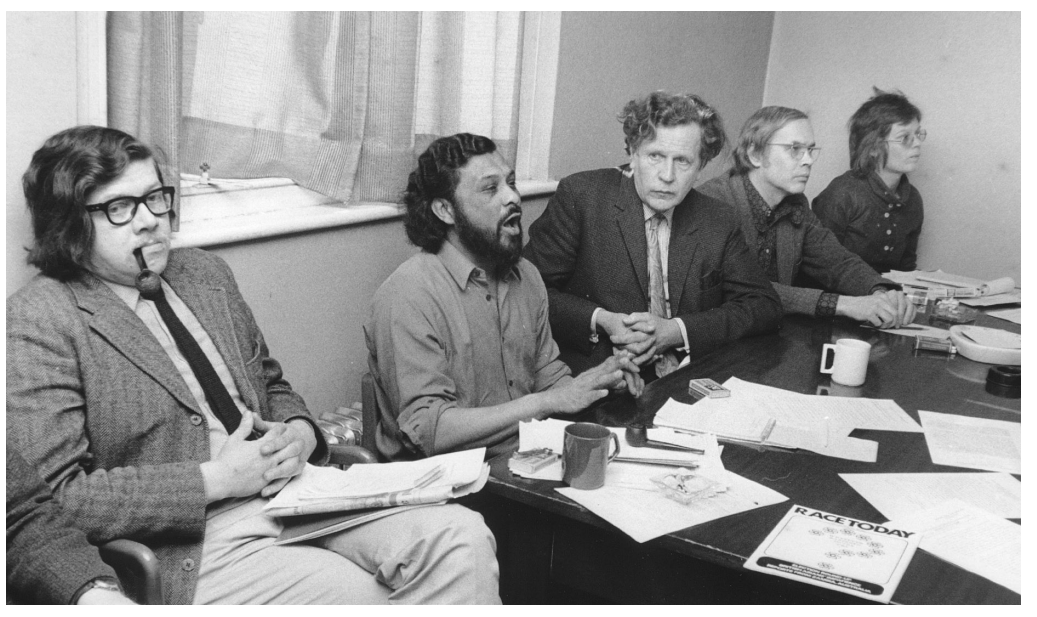

\section{Abstract}

This article looks at the contribution made by Ambalavaner Sivanandan to Black politics and organising in Britain. It reviews some of his most important writings and analyses their significance and influence on Black activism and race studies. Specifically, the article looks at the ways in which class and race intersected in his work and his critical stance towards political elites and advocacy for radical politics.

Keywords: Sivanadan, IRR, Race and Class, racism, black struggle, Labour, colonialism, radical politics

Ambalavaner Sivanandan needs no introduction to scholars of race and class studies in Britain. Whilst I never had the opportunity to meet him, Sivanandan's work was pivotal to my growth as a scholar and activist within Labour politics. Colin Prescod in his Foreword to Sivanandan's collection Catching History in the Wing (2008a) says that for Black British community activists who emerged politically in the 1970's Sivanandan was the most original influence. I would venture to say he remains an influence for many emerging Black activists even today. 
Sivanandan was born on 23 December 1923 in Sri Lanka and migrated to the United Kingdom in 1958 following the anti-Tamil riots. He was the founding editor of the journal Race and Class and was instrumental in reshaping the London based Institute of Race Relations (IRR) from a think tank that was advising government and producing knowledge which 'served the interests of the ruling elite' to an organisation which placed itself between academia and the grassroots and working with and for those who were most discriminated against by British society. A paper titled 'Production of Knowledge at the Institute of Race Relations' by Robin Jenkins in 1971 summed up the situation at the IRR as follows:

The IRR has worked to make the power elite relatively more powerful and knowledgeable and thereby to make the subject (immigrant) population relatively more impotent and ignorant.' (Sivanandan, 2008b: 21).

Chris Mullard (1985) in his fascinating history of the IRR notes that the framework within which the Institute was set up was to contain communism and black liberation within liberal capitalism thus pursuing the political and commercial interests of its funders. Paul Gilroy (1987) makes a similar point when he argued that equating racism solely with far-right extremism denies the normalised racism within political and social formations. Sivanandan was opposed to the IRR council's lack of independence from government departments and overseas funders and led a successful rebellion which turned the Institute 'into a research and political centre of and for the victims of racism'. Sivanandan declared after taking the institute to its radical roots; that the mission of the Institute would henceforth be around critical education through public talks, publications and the library which would 'infiltrate the cloisters of academe... and generate an insurgent politics' (Sivanandan cited in Warmington, 2014: 63). Warmington (2014: 70) argued that Sivanandan was amongst the first black British intellectuals to 'understand that there was a coherent history of black educational activism that needed to be drawn upon in order to avoid the errors of multicultural education.'

Sivanandan's writing emerged at a time when Thatcherism was at its height. He was a fierce critic of free market economy and argued that whilst free market economy determined immigration and economic growth in the country, it was colonial legacy that determined the nature of work for many immigrants. His writing was cutting, rigorous and inspirational to 
Black activists who were fighting racism and poverty. Writing about immigrant labour he said:

Everyone made money on the immigrant worker- from the big time capitalist to the slum landlord- from exploiting his labour, his colour, his customs, his culture... He had been paid for by the country of his origin- reared and raised, as capitalist under development had willed it, for the labour markets of Europe. (Sivanandan, 1976: 349)

Sivanandan made profound interventions on the issues that defined this political moment. He understood the relation between identity politics and class and the ways in which this form of exploitation was part of the State apparatus. He argued in 'Poverty is the New Black' (2001) that the administration and criminal justice system was rife with racism and that institutional racism and popular racism was woven into state racism. At the same time Sivanandan was also critical of the Black struggle being subsumed by the class line. Whilst many Marxists and white radicals maintained that Black oppression was an aspect of class discrimination, Sivanandan argued that despite the common denominator of capitalist oppression, it was not sufficient to bind them together. He notes:

The economic aspects of colonial exploitation may find analogy in white working class history. But the cultural and psychological dimensions of black oppression are quite unparalleled (Sivanandan, 1977: 339).

Sivanandan's politics was radical and often opposed to mainstream political parties. In an insightful roundtable conversation in Marxism Today (1985) with Stuart Hall, Vishnu Sharma and the Labour Party politicians Diane Abbott and Unmesh Desai, he argued that the Labour Party and the larger labour movement in the country had failed to support the struggles of the black working community and incorporate the history of those struggles within the white working class community. He thought black organising within the Labour Party through the creation of black sections was a distraction and consisted of a 'handful of aspiring black middle class people who have been blocked on their way up the Labour hierarchy' (Abbott et al, 1985: 33) and did not necessarily reflect the black working community. Many years later Sivanandan was critical of the Terrorism Act of 2000 passed by the Labour government which gave the Home Secretary power to proscribe any organisation which threatened violence to advance a political, religious or ideological position. He argued that this 
criminalised liberation struggles of those who had fled tyrannies of their own country, and in the process stigmatised them as terrorists. He might have of course been referring to the Liberation Tigers of Tamil Eelam (LTTE) which had embarked on an armed struggle for secession and creating an independent Tamil State in Sri Lanka of which he had remained quite ambivalent (Sivanandan, 2009). Sivanandan's novel, When Memory Dies (1998) documented the sectarian violence of Sri Lanka through three generations of a family for which he was awarded the Commonwealth Writers Prize in 1998. Sivanandan was also critical of the New Labour project and its neoliberal agenda. He firmly believed that the market was antithetical to the good society. He argued that inequality was structured within the market society and the hardships of the recession during the Blair years and later the coalition government (2010-2015) fell unequally on the poor with the promise of free market prosperity stopping with the middle classes. According to him the threat of capitalism was not something abstract but rather the creation of a market state which was given legitimacy through the political culture: 'In sum, neoliberalism has engendered a political culture acceptable to the majority of the electorate and given (electoral) legitimacy to the market state.' (Sivanandan, 2013: 8).

Sivanandan was much more interested in actual community struggles that was taking place across Britain through the workplace, educational establishments and public services. During the 1970s, Black labour force around the country were organising and demanding equal pay and promotion as their white counterparts. A series of strikes were carried out in the East Midlands textile industries including the Mansfield Hosiery Mills in Loughborough in 1972 which saw many of these workers being denied official support from the unions. The later Grunwick strike of 1977 which centred around union recognition and wages also saw national debates about Black workers being exploited and as Amrit Wilson (1997) notes making 'use of the poverty of Asians'. Sivanandan writes that trade union racism was rife and support was denied on grounds of not following correct negotiating procedures. It was black community organisations and associations across the country which came to the aid of these workers. He further argued that Grunwick and Mansfield had shown that through the joint strategies of the State and union leaders, racism and class shaming was being ordained and legitimised. (Sivanandan, 1981).

The 1980s also saw horrendous racist attacks being mounted on Afro-Caribbean and Asian youth in the inner cities by the National Front and British National Movement. The growing 
impunity with which these attacks were carried out and the police indifference to them was alarming. When the community took defending themselves into their own hands, police brutality was swift and as the now famous case of Newham 7 showed, worked actively against black organising and solidarity (Newham Monitoring Project, 1991). Sivanandan points out that when the youth began to emerge in the frontline of black political struggles, they brought with them the wisdom of their elders and their own experiences which were 'implacable of racism and impervious to the blandishments of the State.' (Sivanandan, 2008: 126). A march for the seven Newham youth who were arrested and denied bail by the police brought together members of Asian and Afro-Caribbean communities under a common banner and a shared struggle. Sivanandan writing about this episode notes that the police during this time far from finding the culprits would not acknowledge the attacks as racist and when black people defended themselves 'we are taken to court, penalised and rendered defenceless' (Abbott et al, 1985: 33).

Sivanandan's death on $3^{\text {rd }}$ January 2018 was quietly mourned. As one obituary by Daniel Renwick (2018) best put it, 'memory had forgotten a giant'. Whilst Sivanandan's work in contemporary times has remained confined within academia and radical veterans, his influence on Black political organising across Britain is immeasurable. His thinking and writing on class, immigration, race and globalisation is more important than ever given the right ward shift in global politics which has seen the election of Donald Trump as the President of United States, Brexit and return of austerity politics under a conservative government in Britain and the ever-growing number of migrants coming to Europe fleeing oppressive regimes. Sivanandan's writing provides a way of not only challenging the violence of the present but also understanding it. He will continue to live through his many accomplishments and his writing will continue to provide the weapon of struggle for many of us academics and activists. It would be fitting to end this essay with Siva's words calling for a revolutionary culture.

But to revolutionise a culture, one needs first to make a radical assessment of it. That assessment, that revolutionary perspective, by virtue of his historical situation, is provided by the black man... In his everyday life he fights the particulars of white cultural superiority, in his conceptual life he fights the ideology of white cultural hegemony. In the process he engenders not perhaps a revolutionary culture, but certainly a revolutionary practice within that culture (Sivanandan, 1977: 340-341). 
Bio:

Rohit K Dasgupta is Programme Director and Lecturer in Global Communication and Development at Loughborough University. He is the author of Digital Queer Cultures in India (Routledge, 2017) and co-editor of Friendship as Social Justice Activism (Chicago/Seagull, 2018). He is also involved in labour politics.

\section{Acknowledgements:}

I would like to thank the Institute of Race Relations for permission to use the accompanied image. Also, many thanks to Unmesh Desai, AM for sharing Sivanandan's conversation with him in Marxism Today.

\section{References:}

Abbott, D., Desai, U., Hall, S., Sharma, V and Sivanandan, A (1985) Black Sections: Radical Demand... or Distraction? Marxism Today (September 1985), pp. 31-36

Gilroy, P (1987) There Ain't No Black in the Union Jack: The Cultural Politics of Race and Nation. London: Hutchinson

Mullard, C (1985) Race, Power and Resistance. London: Routledge and Kegan Paul.

Newham Monitoring Project (1991) Newham: The Forging of a Black Community. London: Institute of Race Relations

Renwick, D (2018) Sivanandan: When Memory Forgets a Giant. Red Pepper. Available at: https://www.redpepper.org.uk/sivanandan-when-memory-forgets-a-giant/ (accessed on 18 January 2018)

Sivanandan, A (1976) Race, Class and the State: The Black Experience in Britain. Race and Class, 17(4), pp. 347-368

Sivanandan, A (1977) The Liberation of the Black Intellectual. Race and Class, 18(4), pp. $329-343$

Sivanandan, A (1981) From resistance to rebellion: Asian and Afro-Caribbean struggles in Britain. Race and Class, 23(2-3), pp. 111-152

Sivanandan, A (1998) When Memory Dies. London: Arcadia 
Sivanandan, A (2001) Poverty is the New Black. Race and Class, 43(2), pp. 1-5

Sivanandan, A (2008) Catching History on the Wing: Race, Culture and Globalisation.

London: Pluto Books

Sivanandan, A (2008b) Race and Resistance: The IRR Story. Race and Class, 50(2), pp. 1-30

Sivanandan, A (2009) An Island Tragedy: Buddhist Ethnic Cleansing in Sri Lanka. New Left

Review. Available at: https://newleftreview.org/II/60/a-sivanandan-an-island-tragedy

(accessed on 18 January 2018)

Sivanandan, A (2013) The Market State vs the Good Society. Race and Class, 54(3), pp. 1-9

Warmington, P (2014). Black British Intellectuals and Education: Multiculturalism's Hidden

History. London: Routledge

Wilson, A (1997) Finding a Voice: Asian Women in Britain In H. Mirza (Ed.) Black British

Feminism: A Reader. London: Routledge, pp. 31-35. 